czyli przedmiot wydawałoby się niezbyt frapujący, udało im się przyciągnąć zainteresowanie respondentów i uzyskać wiele informacji dzięki zastosowaniu metodologii generatywnej.

Ostatni panel nosił tytuł „Vision” - wizja, która w przeciągu kilku sekund, które potencjalny użytkownik jest skłonny poświęcić nowym produktom bądź usługom, ma go przekonać, że są one odpowiednie właśnie da niego. Autorem pierwszej prezentacji Containerisation of the web był Konstanin Weiss (Information Architects). Opowiadał on o wypracowanym przez siebie nowym podejściu w projektowaniu usług i serwisów, w którym kontekstem dla wszelkich działań jest organizacja treści ze względu na zadania stojące przed użytkownikami. Matt Lee z Booking.com mówił o tym, jak użyteczne dla poznania rzeczywistych potrzeb użytkowników jest prowadzenie badań poza laboratoriami, w warunkach w jakich w rzeczywistości korzystają oni z serwisów. Wizyty w domach klientów i tam prowadzona obserwacja pozwoliły zidentyfikować słabe i moce strony serwisu. W czasie ostatniego wystąpienia, zamykającego konferencję, Andrea Resmini (Jönköping International Business School) opowiedział zebranym o roli, jaką architektura informacji pełni w dzisiejszym świecie, pełnym różnorodnych technologii i złożoności przekazów, które docierają do użytkowników.

To oczywiście tylko niektóre z zaprezentowanych wystąpień. Szczegółowy program konferencji można znaleźć na stronie http://www.uxpoland.com, wkrótce znajdą się tam również nagrania wszystkich wystąpień. Warto również zwrócić uwagę na dobrą organizację konferencji, która dawała okazję nie tylko do wysłuchania prelekcji, ale również sprzyjała nawiązaniu kontaktów i wymianie doświadczeń.

The Human Experience Conference nie była konferencją naukową. Niektórzy z prelegentów mogli szczycić się ukończeniem najlepszych światowych uczelni, atutem innych było bogate doświadczenie praktyczne. Wszyscy opowiadali o doświadczeniach, które są kluczowe w pracy z użytkownikami. Konferencja ta zdecydowanie zasługuje na uwagę również środowiska badaczy zajmujących się tematyką informacji naukowej, przede wszystkim ze względu na powszechnie ostatnio postulowane zbliżenie świata nauki i biznesu. Projektowanie rozwiązań będących przedmiotem zainteresowania biznesu wymaga prowadzenia badań z zakresu zachowań informacyjnych użytkowników, co było wielokrotnie podkreślane w czasie wystąpień i jest obszarem, w który mogą i powinni angażować się pracownicy akademiccy.

Anna Mierzecka-Szczepańska Instytut Informacji Naukowej i Studiów Bibliologicznych Uniwersytet Warszawski

Nadestano: 12.05.2014.

\title{
„Organizacja wiedzy w XXI wieku: od historycznych wzorców ku przyszłości”. XIII Konferencja Międzynarodowego Towarzystwa Organizacji Wiedzy (ISKO)
}

(Kraków 19-22 maja 2014 r.)

W dniach 19-22 maja 2014 r. w Krakowie odbyła się trzynasta edycja konferencji Międzynarodowego Towarzystwa Organizacji Wiedzy (International Society for Knowledge Organization - ISKO). Organizatorem tegorocznego spotkania był polski oddział ISKO oraz Instytut Informacji Naukowej i Bibliotekoznawstwa Uniwersytetu Jagiellońskiego. Konferencja zbiegła się z 25-leciem działalności ISKO oraz została oficjalnie włączona w obchody 650-lecia Uniwersytetu Jagiellońskiego. Założeniem 
spotkań organizowanych przez ISKO jest umożliwienie wymiany poglądów i doświadczeń w zakresie badań prowadzonych nad problematyką organizacji wiedzy w ramach interdyscyplinarnie pojmowanych studiów informacyjnych. Konferencje ISKO, organizowane w cyklu dwuletnim, są istotnym elementem ogólnoświatowej dyskusji nad bieżącymi problemami teorii i praktyki systemów porządkowania pojęć. Motywem przewodnim tegorocznej konferencji ISKO było hasło,organizacja wiedzy w XXI wieku: od historycznych wzorców ku przyszłości”.

Otwarcie i sesję plenarną zorganizowano w auli Collegium Novum Uniwersytetu Jagiellońskiego. Uroczystego otwarcia konferencji dokonali dr hab. Remigiusz Sapa (dyrektor Instytutu Informacji Naukowej i Bibliotekoznawstwa UJ), prof. dr hab. Wiesław Babik (koordynator Polskiego Oddziału ISKO, UJ) oraz H. Peter Ohly (przewodniczący ISKO). Głos zabrali również przedstawiciele rektora Uniwersytetu Jagiellońskiego i prezydenta miasta Krakowa. Z uwagi na przypadające w tym roku 25-lecie działalności ISKO, symboliczne znaczenie miało zaproszenie dr Ingetraut Dahlberg - jego założycielki i pierwszej przewodniczącej. W krótkim przemówieniu nawiązała ona do historii ISKO oraz omówiła najważniejsze etapy rozwoju tego towarzystwa. Podczas sesji plenarnej, której przewodniczył prof. Piotr Sztompka (UJ), wygłoszono pięć referatów. Jako pierwszy głos zabrał Birger Hjørland (Royal School of Library and Information Science, Dania). Przedmiotem jego wystąpienia była problematyka wykorzystania algebry Boole'a do wyszukiwania informacji w bibliograficznych bazach danych w odniesieniu do stosowanych tam systemów organizacji wiedzy. Jedną z tez B. Hjørlanda była konieczność uwzględnienia w tym kontekście kompetencji informacyjnych użytkowników oraz roli bibliotekarzy i bibliotecznych systemów organizacji wiedzy w mediacji między użytkownikami a oferowanymi zbiorami i usługami informacyjnymi. Referat B. Hjørlanda nie został włączony do tomu pokonferencyjnego, tekst ukaże się w kolejnym zeszycie czasopisma Journal of the Association for Information Science and Technology. Jako drugi wystąpił Michael Buckland (University of Berkeley, USA). Autor scharakteryzował rozwój technologii informacyjnych i ich wpływ na systemy organizacji wiedzy, odnosząc się do ewolucji pisma, druku, technologii telekomunikacyjnych, kopiowania i cyfrowego przetwarzania tekstów. Jego zdaniem, cały czas jesteśmy świadkami i uczestnikami społeczeństwa opartego na dokumentach (ang. document society), a wyrażenie społeczeństwo informacyjne jest jedynie tego metaforą. Po krótkiej przerwie wygłoszono trzy referaty. Dagobert Soergel (University of Buffalo, USA) przedstawił problematykę wykorzystania modeli organizacji struktur pojęciowych jako narzędzi strukturyzacji i wizualizacji treści o charakterze edukacyjnym. Autor odniósł się do modelu związków encji, koncepcji faset i teorii ram, map pojęciowych oraz grupy prostszych schematów porządkowania pojęć. D. Soergel postawił tezę, że wykorzystanie modeli konceptualnych leżących u podstaw systemów organizacji wiedzy w organizacji treści i wizualizacji informacji w dokumentach przeznaczonych do celów edukacyjnych, korzystnie wpływa na efektywność przyswajania tego rodzaju informacji. Jako kolejny głos zabrał Mieczysław Muraszkiewicz (Politechnika Warszawska), który wraz z Bruno Jacobfeuerbornem (Deutsche Telekom AG, Niemcy) przygotowali wystąpienie na temat koncepcji Big Data i zmian we współczesnej nauce. Autor omówił ewolucję kluczowych paradygmatów w nauce dochodząc do konkluzji, że jesteśmy świadkami kolejnej zmiany i nastania nowego paradygmatu, w którym to gromadzone przez nas dane oraz metody i możliwości ich przetwarzania będą determinowały kierunki rozwoju nauki. Jako ostatni w sesji plenarnej, głos zabrał urzędujący przewodniczący ISKO - H. Peter Ohly (German Social Science Infrastructure Services, Niemcy). Tematem jego wystąpienia były socjologiczne aspekty interpretacji wiedzy i systemów organizacji wiedzy. Autor odniósł się do tych zagadnień również z punktu widzenia filozofii nauki, rozwoju technologii informacyjnych oraz w dosyć dużym uproszczeniu - w kontekście ewolucji World Wide Web.

Obrady podczas kolejnych dni konferencji miały miejsce już na Kampusie Uniwersytetu Jagiellońskiego w nowoczesnym budynku Wydziału Zarządzania i Komunikacji Społecznej. Konferencja przyjęła formę sesji równoległych. W związku z tym w dalszej części zostaną omówione sesje, w których uczestniczył sprawozdający. Drugiego dnia odbyły się sesje równoległe w części porannej, przedpołudniowej i popołudniowej. Były to trzy bloki tematyczne: „Narzędzia organizacji wiedzy”, 
„Organizacja i reprezentacja wiedzy w systemach informacyjno-wyszukiwawczych” oraz „Organizacja wiedzy w bibliotekach”. Sesji „Narzędzia organizacji wiedzy” przewodniczyli kolejno: prof. Barbara Sosińska-Kalata (Uniwersytet Warszawski), prof. Jose Augusto Guimaraes (Sao Paolo State University, Brazylia) oraz prof. Richard Smiraglia (University of Wisconsin, USA). Tematyka wystąpień była mocno zróżnicowana, ale wspólnym mianownikiem referatów była koncentracja uwagi autorów na różnych aspektach badania i wykorzystania systemów organizacji wiedzy. W części porannej wygłoszono pięć referatów. Deborah Lee (City University London, Wielka Brytania) przedstawiła problematykę wpływu, jaki mają na siebie równolegle rozwijane systemy klasyfikacyjne. Autorka zaprezentowała interesującą metodologię badań nad tym zjawiskiem. Równie ciekawe wystąpienie poświęcono rozwojowi koncepcji warrant jako podstawy metodologicznej systemów organizacji wiedzy. Lynn Howarth (Faculty of Information Studies, University of Toronto, Kanada) przedstawiła typologię takich założeń na podstawie literatury przedmiotu oraz badań własnych nad wybranymi systemami porządkowania pojęć. W sesji wystąpili również Melodie J. Fox (University of Wisconsin, USA) prezentacja na temat organizacji pojęć z zakresu gender w różnych wydaniach Klasyfikacji Dziesiętnej Deweya, Joseph T. Tennis (University of Washington, USA) - wystąpienie dotyczące metafory gmachu w odniesieniu do ewolucji klasyfikacji bibliotecznych, Anna Vukadin (National and University Library, Chorwacja) - referat na temat wykorzystania fasetowej organizacji pojęć w klasyfikacjach uniwersalnych, na przykładzie działu 72 Architektura w Uniwersalnej Klasyfikacji Dziesiętnej. Część przedpołudniową sesji wypełniły wystąpienia dotyczące problemów lingwistycznych i terminologicznych w kontekście systemów organizacji wiedzy. Dotyczyły one m.in. automatycznej kategoryzacji fraz rzeczownikowych wykorzystywanych w procesie wyszukiwania informacji (Angaldo Lopez Martin, Federal University of Minas Gerais, Brazylia) oraz wykorzystania klasyfikacji Information Coding Classification do wyszukiwania informacji leksykograficznej w zbiorach Linked Data (Ernesto William De Luca, University of Applied Sciences, Niemcy). W części popołudniowej zaplanowano siedem wystąpień. Tematyka referatów dotyczyła m.in.: reprezentacji klasyfikacji fasetowych jako ontologii (Devika P. Madalli, Indian Statistical Institute, Indie), wykorzystania teorii terminologicznych do projektowania systemów organizacji wiedzy (Jadwiga Woźniak-Kasperek, UW), pojęcia kontekstu według filozofii Gottloba Fregego w odniesieniu do organizacji struktur pojęciowych (Jolanta Szulc, UŚ) oraz metodyki mapowania tezaurusów (Jae-wook Ahn, University of Buffalo, USA).

Sesja równoległa dotycząca organizacji i reprezentacji wiedzy w systemach informacyjno-wyszukiwawczych została podzielona na dwie części, którym przewodniczyli kolejno dr Vera Dodebei (Federal University of the State of Rio de Janeiro, Brazylia) oraz dr Devika P. Madali (Indian Statistical Institute, Indie). W sesji zaplanowano łącznie 11 wystąpień, jednak w kilku przypadkach autorzy nie mogli być obecni podczas konferencji. Problematykę wystąpień dosyć umownie wyznaczało pojęcie organizacji i reprezentacji wiedzy. Wystąpienia miały charakter zarówno teoretyczny, jak i bazowały na pracach wdrożeniowych i badaniach empirycznych. Prezentowane problemy obejmowały m.in. zagadnienia subiektywizmu i inklinacji w opisie rzeczowym (Jose Augusto Guimaraes, Sao Paolo State University, Brazylia), wizualizacji tekstów za pomocą map pojęciowych (Hanna Batorowska, Uniwersytet Pedagogiczny, Kraków), analizy domenowej obszaru biotechnologii (Juliana Assis, Universidade Federal de Minas Gerais, Brazylia), profilowania użytkowników w kontekście ich interakcji z sieciowymi mechanizmami wyszukiwania informacji (Bernard Ijesunor Akhigbe, Obafemi Awolowo University, Nigeria), wnioskowania poziomu kompetencji użytkowników na podstawie zastosowania algorytmów kategoryzacji ich zapytań (Olubunmi Akbele, University of Ibadan, Nigeria), projektowania tezaurusa z uwzględnieniem podejścia user warrant (Philip Hider, Charles Sturt University, Australia) oraz wyszukiwania fasetowego w systemach informacyjnych typu discovery (Katarzyna Materska, Biblioteka Uniwersytetu im. Kardynała Stefana Wyszyńskiego). Nie wygłoszono dwóch referatów autorów L. Hajibayova i E.K. Jacob, dotyczących badań nad tagowaniem. Ostatnią sesję drugiego dnia konferencji poświęcono problematyce organizacji wiedzy w odniesieniu do bibliotek, zarówno tradycyjnych, jak i cyfrowych. Wygłoszono osiem referatów poruszających problematykę m.in. relacji między organizacją 
wiedzy a cyfrową humanistyką (Widad Mustafa El Hadi, University of Lille, Francja), automatycznego indeksowania dokumentów z wykorzystaniem koncepcji ikonologii Panofskiego (Marcia L. Zeng, Kent State University, USA), eksploracyjnego modelu wyszukiwania informacji za pomocą systemów organizacji wiedzy w kolekcjach danych powiązanych - Linked Data (Athena Sabala, Kent State University, USA), czy też analizy wdrożeń systemów informacyjnych typu discovery w bibliotekach w Hiszpanii i Brazylii (Blanca Rodriguez Bravo, University of Leon, Hiszpania). W sesji tej wystąpili również przedstawiciele Centralnego Instytutu Ochrony Pracy z referatami na temat indeksowania zasobów katalogów bibliotecznych przez wyszukiwarki internetowe (Agnieszka Młodzka-Stybel) oraz sieci informacyjnych na przykładzie obszaru bezpieczeństwa pracy (Barbara Szczepanowska).

Tego dnia odbyło się również zebranie członków ISKO i miały miejsce wybory nowego zarządu. Prezydentem ISKO na kadencję 2014-2018 wybrano Josepha Tennisa. Jego pierwszym zastępcą został ustępujący H. Peter Ohly a drugim zastępcą wybrano Stellę Dextre Clark (niezależny konsultant, Wielka Brytania). Na sekretarza ISKO wybrano Amosa Davida (Lorraine University, Francja).

Trzeciego dnia odbyły się cztery sesje, również w trybie równoległym. Były to panele: „Organizacja wiedzy w edukacji”, „Metody organizacji wiedzy”, „Organizacja wiedzy w obszarach specjalistycznych”, "Obszar badawczy i epistemologia organizacji wiedzy”. W sesji poświęconej metodom organizacji wiedzy, której przewodniczył dr Joseph T. Tennis, wygłoszono pięć referatów. K.S. Raghavan (PES Institute of Technology, Indie) przedstawił fasetową analizę przeglądu piśmiennictwa na temat fasetowej koncepcji organizacji wiedzy. Richard Smiraglia wraz ze swoją doktorantką Ann M. Graph (oboje z University of Wisconsin, USA) przedstawili metodologię badań bibliometrycznych oraz analizy domeny „narodowość i rasa” w encyklopedii miasta Milwaukee. Grant Campbell (University of Western Ontario, Kanada) przedstawił interesujący sposób zastosowania analizy fasetowej w dokumentacji zachowań osób cierpiących na demencję. Claudio Gnoli (University of Padvia, Włochy) omówił poglądy Marca Blocha związane z klasyfikacją i kategoryzacją dziedzin wiedzy. Jihee Beak (University of Wisconsin, USA) przedstawiła wyniki ilościowej i jakościowej analizy fasetowej tekstów z materiałów konferencyjnych organizowanych przez Dublin Core Metadata Initiative. W części przedpołudniowej odbyło się również, zaplanowane na kolejny dzień, wystąpienie Barbary Sosińskiej-Kalaty (Uniwersytet Warszawski). Autorka przedstawiła problemy standaryzacji i semantyzacji jako istotne kwestie w rozwoju systemów organizacji wiedzy. W sesji dotyczącej epistemologii w organizacji wiedzy prowadzonej przez prof. Renato Rocha Souza (School of Applied Mathematics, Brazylia), wygłoszono siedem z ośmiu zaplanowanych referatów. Dotyczyły one m.in. dekonstrukcji pojęcia pamięci społecznej (Vera Dedebei, Federal University of the State of Rio de Janeiro, Brazylia), roli metafory w organizacji struktur pojęciowych (Marek Hetmański, Uniwersytet Marii Skłodowskiej Curie), potrzeby uwzględnienia relatywizmu epistemologicznego w projektowaniu systemów organizacji wiedzy (Michael Kleinberg, Humboldt University, Niemcy), czy też rewizji podstaw kategorialnych systemów porządkowania pojęć (K.S. Raghavan, PES Institute of Technology, Indie).

W części popołudniowej zorganizowano panel dyskusyjny dotyczący kształcenia w zakresie problematyki organizacji wiedzy. Moderatorem panelu był dr hab. Remigiusz Sapa (UJ) a członkami doświadczeni dydaktycy: Rahmatollah Fattahi (Ferdowsi University of Mashhad, Iran), Lee Hur-Li (University of Wisconsin, USA), Devika P. Madalli (Indian Statistical Institute, Indie), Sidhom Sahbi (Lorraine University \& LORIA, Francja), Jadwiga Woźniak-Kasperek (UW), Marcia L. Zeng (Kent State University, USA), Maja Zumer (University of Ljubljana, Słowenia). W trakcie krótkich wypowiedzi prelegentów przedstawiono sytuację w poszczególnych ośrodkach akademickich, ze szczególnym uwzględnieniem treści programowych związanych z organizacją wiedzy. Wielokrotnie stwierdzano problem braku aktualnych podręczników obejmujących wieloaspektowo tę problematykę. B. Hjørland sceptycznie odniósł się do możliwości przedstawienia studentom gruntownych podstaw organizacji wiedzy, twierdząc, że są one często oparte na sprzecznych teoriach.

Ostatniego dnia konferencji odbyły się tylko dwie równoległe sesje oraz panel dyskusyjny. Były to sesje zatytułowane „Historia i przyszłość organizacji wiedzy” oraz „Systemy organizacji wiedzy”. 
W sesji dedykowanej systemom porządkowania pojęć, której przewodniczył Claudio Gnoli, wygłoszono cztery z pięciu zaplanowanych referatów. Thomas M. Dousa (University of Illinois, USA) omówił problem postaw epistemologicznych w wybranych klasyfikacjach biblioteczno-bibliograficznych, które określił mianem eklektycznych. Rick Szostak (University of Alberta, Kanada) z kolei postawił tezę, że organizacja wiedzy to jedyny obszar badawczy z tak dużym potencjałem intelektualnym, który jest w stanie redukować sceptycyzm we współczesnej nauce. Thomas M. Dousa w kolejnym swoim wystąpieniu dokonał analizy systemu kategorialnego leżącego u podstaw systemu Otto Kaisera. Rebecca Green (OCLC, USA) przedstawiła interesującą metodologię automatycznej derywacji faset na podstawie przetwarzania fraz rzeczownikowych pochodzących z tytułów dokumentów z bazy WorldCat.

Ostatnim punktem programu konferencji była dyskusja panelowa moderowana przez prof. Rebeccę Green, w której wzięli udział: prof.dr hab. Wiesław Babik, prof. David Amos, prof. Vera Dodebei, Claudio Gnoli, H. Peter Ohly, prof. Rosa San Segundo (University of Madrid Carlos III, Hiszpania) oraz dr Joseph T. Tennis. Tematem dyskusji była przyszłość organizacji wiedzy w kontekście zmian społecznych i technologicznych. Podczas wypowiedzi wielokrotnie powtarzały się stwierdzenia o konieczności współpracy i wymiany doświadczeń z przedstawicielami obszaru technologii Sieci Semantycznej oraz Architektury Informacji. D. Soergel stwierdzil, że organizacja wiedzy powinna być częścią kursów w zakresie kształtowania kompetencji informacyjnych, ponieważ stosowane tam analityczno-syntetyczne metody konceptualizacji są przydatne do rozwiązywania problemów informacyjnych. Zarówno podczas wystąpień, jak i w trakcie panelu często podejmowano zagadnienia podstaw epistemologicznych systemów organizacji wiedzy oraz kwestii metodologicznych (user warrant i cultural warrant). Wiąże się to z koniecznością uwzględnienia podczas projektowania takich narzędzi, realnych potrzeb i kompetencji ich użytkowników. I. Dahlberg stwierdziła, że rozwijane systemy organizacji wiedzy powinny być oparte na teorii systemów. Po zakończonej dyskusji organizatorzy dokonali oficjalnego zamknięcia konferencji.

Tegoroczna konferencja ISKO stała na wysokim poziomie, zarówno pod względem merytorycznym, jak i organizacyjnym. Organizatorzy podjęli wiele trudu, aby prelegenci i słuchacze mieli komfortowe warunki do wystąpień i dyskusji. Każdy z uczestników otrzymał podczas rejestracji tom z materiałami pokonferencyjnymi, co pozwoliło przygotować się do dyskusji po wystąpieniach. Na cztery dni obrad zaplanowano ponad 60 referatów. Z jednej strony pokazuje to duże zainteresowanie problematyką organizacji wiedzy badaczy, którzy reprezentowali różne dyscypliny i specjalności, z drugiej - wymaga od słuchaczy podejmowania decyzji związanych z wyborem interesujących ich sesji. Z punktu widzenia prelegentów duża liczba referatów oznaczała również konieczność przestrzegania ram czasowych wystąpień (ok.15 minut) oraz często koncentracji na kluczowych kwestiach podejmowanych przez nich problemów badawczych. Taka forma nie sprzyja dyskusjom, które często musiały być przenoszone do kuluarów.

W konferencji wzięło udział ok. 100 osób z ponad 130 zarejestrowanych. Prelegenci i słuchacze reprezentowali 26 państw z całego świata. Ponad 30\% uczestników stanowili Polacy a dalej uczestnicy z USA (15\%), Brazylii (13\%), Kanady (6\%), Niemiec (5\%). Z 42 zarejestrowanych uczestników z Polski, 15 przygotowało wystąpienia, z czego dwa dwuautorskie. Polscy prelegenci to w większości reprezentanci ośrodków uniwersyteckich (Uniwersytety: Jagielloński, Marii-Curie Skłodowskiej, Pedagogiczny w Krakowie, Śląski, Warszawski,) a także Akademii Ignatianum w Krakowie, Biblioteki Uniwersytetu Kardynała Stefana Wyszyńskiego, Centralnego Instytutu Ochrony Pracy oraz Ośrodka Przetwarzania Informacji. Podczas konferencji można było również skorzystać z oferty wydawnictwa Ergon Verlag, które przygotowało zestaw publikacji na temat organizacji wiedzy, po obniżonych cenach.

Marcin Roszkowski Instytut Informacji Naukowej i Studiów Bibliologicznych Uniwersytet Warszawski

Nadestano: 06.06.2014. 